\title{
Oxidation of electroless Ni-P coated AISI 430 alloy and effect of pre-reduction
}

\author{
Mark K. King Jr. ${ }^{1}$ Manoj K. Mahapatra ${ }^{1}$ (D)
}

Received: 31 January 2020 / Accepted: 16 March 2020 / Published online: 19 March 2020

(c) Springer Nature Switzerland AG 2020

\begin{abstract}
The oxidation behavior of electroless Ni-P coated AISI 430 alloy was investigated at $800^{\circ} \mathrm{C}$ in moisture-saturated $(\sim 3 \%$ $\left.\mathrm{H}_{2} \mathrm{O}\right)$ air. Effect of pre-reduction in dry hydrogen $\left(\mathrm{Ar}-3 \% \mathrm{H}_{2}\right)$ at $800^{\circ} \mathrm{C}$ on the oxidation behavior of the Ni-P coated AISI 430 was also studied. Microstructure, chemical composition, and compound/oxide phase formation across the oxide layer were analyzed by scanning electron microscopy, energy dispersive spectroscopy, and X-ray diffraction techniques. Iron oxide $\mathrm{Fe}_{2} \mathrm{NiO}_{4}$ spinel along with other oxide and spinel phases are found in the multilayered oxide scale for both the $\mathrm{Ni}$-P coated and pre-reduced $\mathrm{Ni}-\mathrm{P}$ coated AISI 430 alloy. Ni-P coating crystallization and oxidation initiates the oxidation for the electroless sample. $\mathrm{Ni}_{3} \mathrm{P}$ and $\mathrm{FeNi}_{3}$ intermetallic compounds formed during reduction initiates the oxidation of the pre-reduced sample.
\end{abstract}

Keywords Ni-P coating · Oxidation · Pre-reduction · Spinel · Iron oxide

\section{Introduction}

Coatings on various surfaces are common to improve corrosion and wear resistance, and functional properties. The performance of a coating primarily depends on its composition, adherence with the substrate, chemical stability, and compatibility and mechanical integrity with the substrate in application environment. Nickel coating finds wide range of applications for its excellent corrosion resistance, tribological properties, and functional properties. Electroless deposition, an autocatalytic method, of nickel has penetrated into wide array of commercial and niche markets $[1,2]$ ranging from engineering tools, offshore wind turbine [3], aerospace [4], and heat exchangers in petroleum industries [5] to solar absorbers for space applications [6].

Common reductants such as sodium hypophosphite, sodium borohydride, or hydrazine are added in the bath for electroless nickel deposition, which form $\mathrm{Ni}-\mathrm{P}, \mathrm{Ni}-\mathrm{B}$, or $\mathrm{Ni}$ coatings, respectively [7]. Ni-P coating has been extensively investigated. Increasing P-content increases the corrosion resistance and electrical resistivity $[8,9]$. Increase in P content up to $\sim 8$ at $\%$ increases the hardness and wear resistance of the coating $[10,11]$.

The high temperature properties of electroless nickel coating has also been studied. The hardness of Ni-P coating increases up to $400{ }^{\circ} \mathrm{C}$ due to precipitation of crystalline $\mathrm{Ni}_{3} \mathrm{P}, \mathrm{Ni}_{5} \mathrm{P}_{2}$, and $\mathrm{Ni}_{12} \mathrm{P}_{5}$ phases [2]. Electrical resistivity and non-magnetic property also improves $[12,13]$. Nickel coating has been investigated to decrease electrical resistance of chromia forming ferritic steel, the metallic interconnect, for high temperature $\left(650-800{ }^{\circ} \mathrm{C}\right)$ solid oxide fuel cell (SOFC) application [14]. Nickel coating decreases chromium vaporization from the ferritic steel $[14,15]$. Nickel oxide and spinel at the oxide surface attributes to these effects. These studies do not provide oxidation

Mark K. King and Manoj K. Mahapatra have equally contributed.

$\triangle$ Manoj K. Mahapatra, mkmanoj@uab.edu | 'Department of Materials Science and Engineering, University of Alabama at Birmingham, Alabama, USA. 
mechanism of nickel coated ferritic steel although inform about the oxide phases at the surface and interfaces.

$\mathrm{Ni}-\mathrm{P}$ coating interaction with metallic substrates is also studied [16-19]. $\mathrm{FeNi}_{3}$ intermetallic layer formation due to nickel diffusion into a carbon steel followed by a $\mathrm{Ni}_{3} \mathrm{P}$ layer and outward diffusion of phosphorous from the coating/steel interface are reported both for $\mathrm{Ni}-\mathrm{P}$ coated steel annealed at $800^{\circ} \mathrm{C}$ in air [16] and at $650^{\circ} \mathrm{C}$ in argon [18]. Formation of $\mathrm{NiO}$ at $607^{\circ} \mathrm{C}$ and $\mathrm{Fe}_{x} \mathrm{Ni}_{y} \mathrm{O}$ at $\geq 695^{\circ} \mathrm{C}$ is reported for a $\mathrm{Ni}-\mathrm{P}$ coated iron annealed in air [17] while the other study does not report any oxide [16]. Iron diffusion from steel and subsequent formation of $\mathrm{Fe}_{2} \mathrm{O}_{3}$ and $(\mathrm{Fe}, \mathrm{Ni})_{3} \mathrm{O}_{4}$ has been reported due to oxidation of $\mathrm{Ni}-\mathrm{P}$ coated steel substrate [19]. All these studies show that phosphorous does not participate in forming oxides; indeed, it may provide a diffusion barrier layer. It is worthy to investigate further the role of $\mathrm{Ni}-\mathrm{P}$ layer on oxidation of chromia forming ferritic steel-the aim of our study.

We have investigated the oxidation of an electroless $\mathrm{Ni}-\mathrm{P}$ coated AISI 430 isothermally at $800^{\circ} \mathrm{C}$ in moisture saturated $\left(\sim 3 \% \mathrm{H}_{2} \mathrm{O}\right)$ air for $100 \mathrm{~h}$. The composition of AISI 430 is similar, if not identical, to the SOFC metallic interconnects as given in Table 1 [20]. Moisture saturated air replicates the SOFC cathode environment. We have also studied the oxidation of the Ni-P coated AISI 430 prereduced in $\mathrm{Ar}-3 \% \mathrm{H}_{2}$.

\section{Materials and methods}

$2.54 \mathrm{~cm} \times 2.54 \mathrm{~cm} \times 0.06 \mathrm{~cm}$ AISI 430 coupons (MSC Industrial Supply (o. USA) were cleaned and nickel coated by a proprietary electroless deposition method (Advanced Technical Finishing, USA) in accordance to MIL-C-26074 Class 1 . One set of the electroless nickel coated AISI 430 coupons were reduced at $800^{\circ} \mathrm{C}$ for $2 \mathrm{~h}$ at $3^{\circ} \mathrm{C} \mathrm{min}^{-1}$ ramp rate in $\mathrm{Ar}-3 \% \mathrm{H}_{2}$ gas (certified) at $100-\mathrm{sccm}$ flow rate. The reduced samples were designated as $\mathrm{R}$-electroless.

The electroless and R-electroless samples were oxidized in a moisture saturated $\left(\sim 3 \% \mathrm{H}_{2} \mathrm{O}\right)$ flowing air (ultra-high purity, $100-\mathrm{sccm}$ flow rate) at $800^{\circ} \mathrm{C}$ for $10 \mathrm{~h}, 20 \mathrm{~h}, 50 \mathrm{~h}$, and $100 \mathrm{~h}$ at $3^{\circ} \mathrm{C} \mathrm{min}{ }^{-1}$ ramp rate in an atmosphere controlled furnace (Lindberg, Model 54233, Waterson, WI USA). Air was flown through deionized water at room temperature to be moisture-saturated. The photograph of the experimental set up is shown in Fig. 1. The oxidation time was cumulative. Therefore, the samples oxidized for $100 \mathrm{~h}$ experienced four thermal cycles. The oxidized samples were weighed using an analytical balance (Mettler Toledo, Model AG245, Switzerland) to determine the oxidation rate.

X-ray diffractometer (XRD) (Siemens D500, KRISTALLOFLEX DACO-MP 710/710 H)) was used to identify the crystalline compounds. The samples were scanned in
Table 1 Nominal compositions (wt\%) of metallic interconnects for solid oxide fuel cell systems [20]

\begin{tabular}{lllllllllllll}
\hline Interconnect & $\mathrm{Fe}$ & $\mathrm{Cr}$ & $\mathrm{Mn}$ & $\mathrm{Ti}$ & $\mathrm{Si}$ & $\mathrm{Al}$ & $\mathrm{C}$ & $\mathrm{S}$ & $\mathrm{P}$ & $\mathrm{Ni}$ & $\mathrm{Nb}$ & $\mathrm{Re}$ \\
\hline Crofer 22 APU & 76.59 & 22.80 & 0.45 & 0.08 & & & 0.005 & 0.002 & 0.016 & & & 0.06 \\
AISI 441 & 80.68 & 17.60 & 0.33 & 0.18 & 0.47 & 0.045 & 0.01 & 0.001 & 0.024 & 0.20 & 0.46 & - \\
AISI 430 & 82.36 & 16.94 & 0.57 & - & 0.13 & - & - & - & - & - & - & - \\
\hline
\end{tabular}

AISI 430 composition is determined from EDS analysis

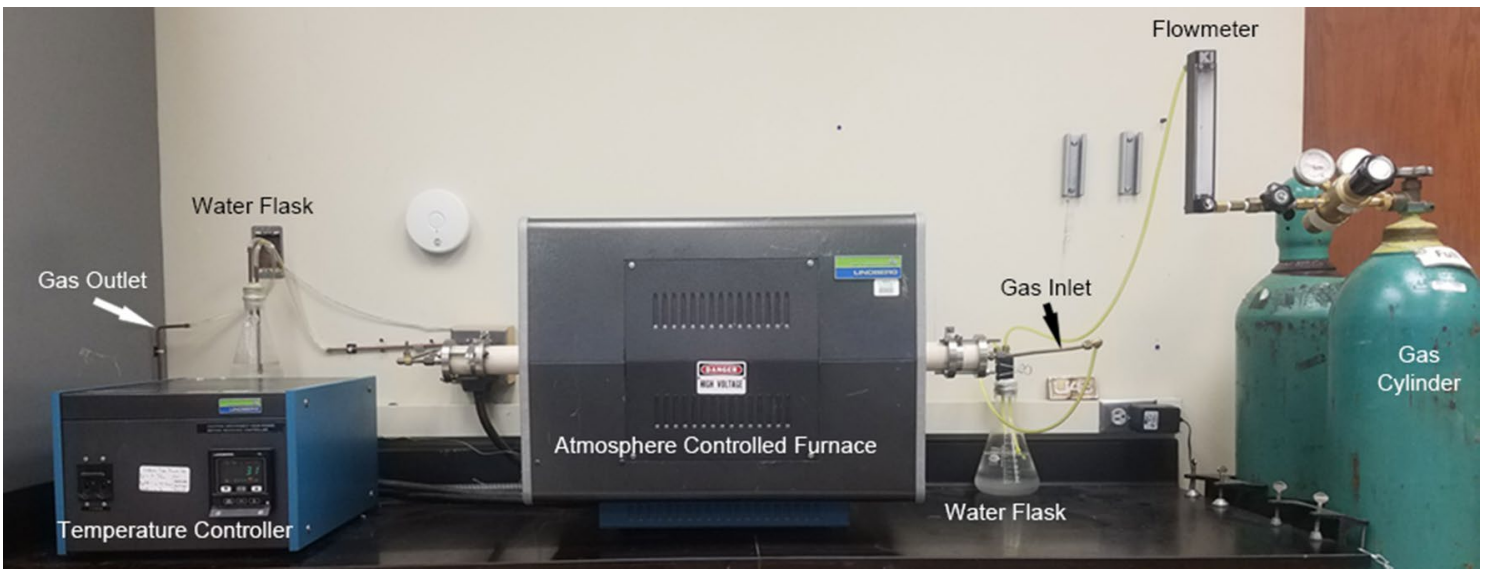

Fig. 1 Photograph of the experimental set-up for oxidation study

SN Applied Sciences

A SPRINGER NATURE journal 
$15-80^{\circ} 2 \theta$ range with $0.04^{\circ}$ step size using $\mathrm{Cu}$ Ka radiation $(\lambda=1.5406 \AA)$ and Ni filter.

Scanning electron microscope (SEM) (FEI Quanta 650 FEG, USA) was used to analyze the surface morphology and interfacial microstructure of the as-received and oxidized samples. The R-electroless sample was coated with $\mathrm{Ni}-\mathrm{Cu}$ topcoat and the oxidized samples were coated with a $\mathrm{Ni}$ topcoat to prevent the original coating and oxide layer from spallation during sample preparation for investigating interfacial microstructure. The cross-sections of samples were polished to optical finish. The elemental composition of the coated substrate and oxide layer was determined by energy dispersive spectrometer (EDS, AMETEK EDAX) attached to the SEM. The EDS spot analysis provides the compositional variation for different phases and/or layers although the spatial resolution $(>1 \mu \mathrm{m})$ and fluorescence effect limits the accuracy of the quantitative analysis [21]. The elemental compositions are reported in atomic percent (at\%). EDS line scan profile was collected to obtain elemental distribution across the interface. Elemental mapping visually complements EDS spot and line scan analysis.

\section{Results and discussion}

\subsection{Coating characteristics}

The electroless coating is uniform as seen from the surface morphologies in Fig. 2a. The nickel coating is $5.24 \pm 0.10 \mu \mathrm{m}$ thick (Fig. 2b), adheres well with the AISI 430 substrate, and contains $18.4 \pm 2.6$ at\% phosphorus as detected by SEM-EDS analysis. The XRD plot in Fig. 3 confirms that the electroless $\mathrm{Ni}-\mathrm{P}$ coating is amorphous.

Surface morphology of the R-electroless sample in Fig. 4a shows that grains are surrounded by bright particles $(\sim 0.24 \pm 0.02 \mu \mathrm{m})$. The appearance of the grains is similar to crystalline phases $(0.37 \pm 0.07 \mu \mathrm{m})$ in an amorphous matrix. The grains are enriched of nickel and phosphorous $(46.6 \pm 1.9 \mathrm{Ni}, 12.2 \pm 0.6 \mathrm{Fe}, 22.4 \pm 0.88 \mathrm{P}, 0.6 \pm 0.1 \mathrm{Cr}$, $0.2 \pm 0.1 \mathrm{Mn}, 18.1 \pm 1.7 \mathrm{O}$ ). The bright particles at the grain boundaries contain $25.3 \pm 6.7 \mathrm{Ni}, 11.3 \pm 1.1 \mathrm{Fe}, 15.3 \pm 2.2$ $\mathrm{P}, 4.7 \pm 2.9 \mathrm{Cr}, 0.6 \pm 0.4 \mathrm{Mn}, 42.7 \pm 6.6 \mathrm{O}$. Higher chromium and oxygen content at the grain boundaries than those in the grains suggests that the bright particles are $\mathrm{Cr}_{2} \mathrm{O}_{3}$. Pores (marked with dotted circle) are observed at the grain boundaries for two plausible reasons. Firstly, amorphous $\mathrm{Ni}-\mathrm{P}$ coating crystallizes into $\mathrm{Ni}$ and $\mathrm{Ni}_{3} \mathrm{P}$ at $\leq 800^{\circ} \mathrm{C}$ [22-24]. Volume shrinkage during crystallization of amorphous $\mathrm{Ni}-\mathrm{P}$ coating causes pore formation. Secondly, Ar- $3 \% \mathrm{H}_{2}$ gas likely contains $\leq 1$ ppm $\mathrm{H}_{2} \mathrm{O}$ as impurity with a $4.2 \times 10^{-23}$ atm. $\mathrm{PO}_{2}$ calculated by HSC Chemistry 9.0. Hydrogen dissolution in nickel and presence of slight $\mathrm{O}_{2}$
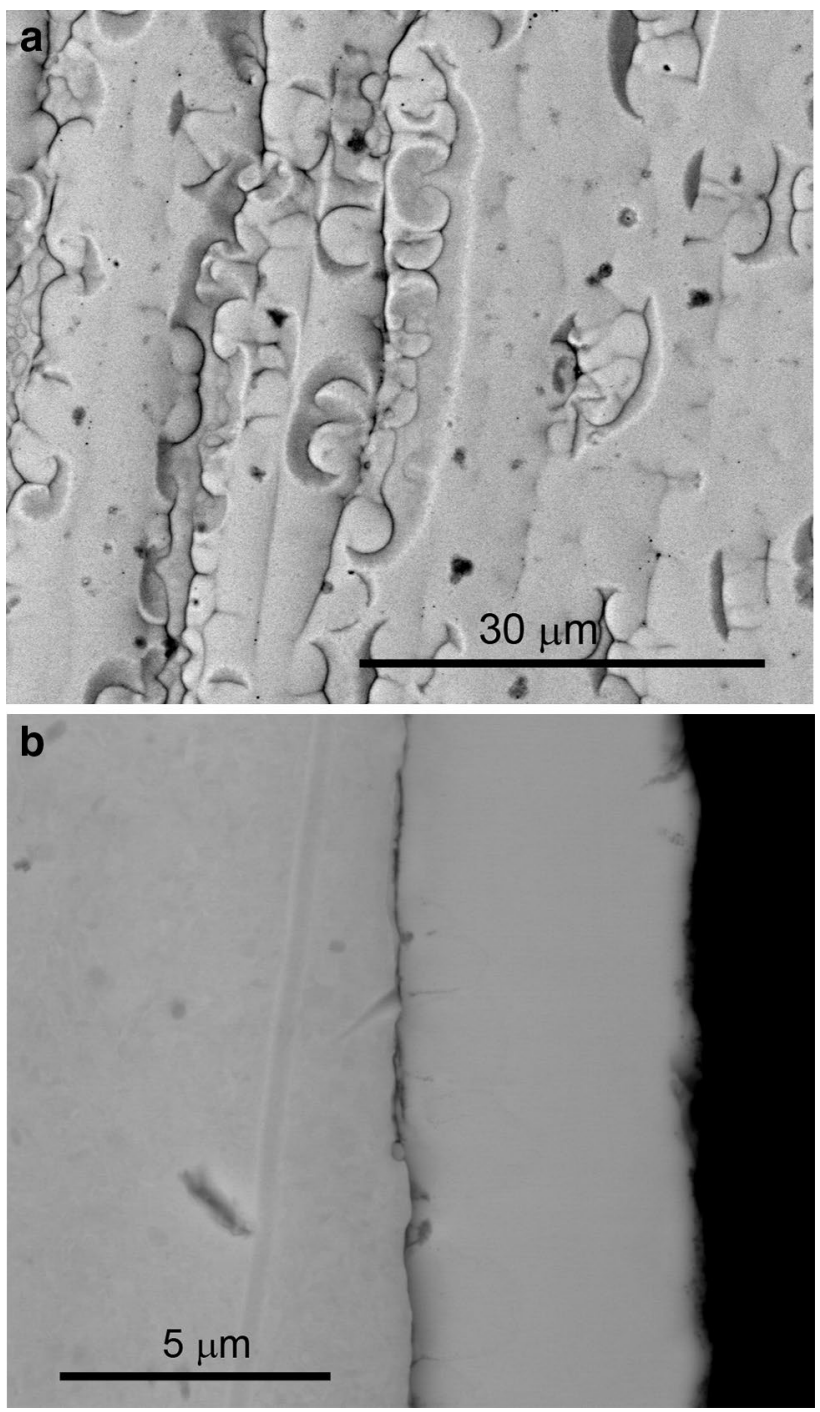

Fig. 2 SEM images of as-received electroless nickel coated AISI 430 alloy: a surface, $\mathbf{b}$ cross-section

(<1 ppm) favors vacancy agglomeration and subsequent growth of pores at the grain boundaries [25].

Oxygen diffuses through the pores and grain boundaries to form $\mathrm{Cr}_{2} \mathrm{O}_{3}$ by internal oxidation. $\mathrm{Cr}_{2} \mathrm{O}_{3}$ is stable up to $\sim 10^{-27}$ atm. $\mathrm{PO}_{2}$ at $800{ }^{\circ} \mathrm{C}$ according to the Ellingham diagram [26].

The cross-sectional SEM image of R-electroless in Fig. 3b shows a $4.63 \pm 0.80 \mu \mathrm{m}$ interaction layer. Dark (arrow marked) phases are observed in the interaction layer and adjacent to the substrate. The interaction layer is nickel and phosphorous rich $(5.9 \pm 0.2 \mathrm{Fe}, 66.0 \pm 0.2 \mathrm{Ni}, 28.0 \pm 0.3$ P) while the dark phase is chromium-rich $(13.7 \pm 2.0 \mathrm{Fe}$, $24.9 \pm 2.4 \mathrm{Cr}, 2.4 \pm 0.1 \mathrm{Mn}, 26.0 \pm 2.1 \mathrm{Ni}, 40.8 \pm 3.0 \mathrm{O}$ ).

The EDS line scan profile in Fig. 5 shows that: (1) iron decreases but nickel increases at/near the interaction layer, (2) chromium, manganese, and oxygen are the highest at 
Fig. 3 XRD plots of as-received electroless and R-electroless samples

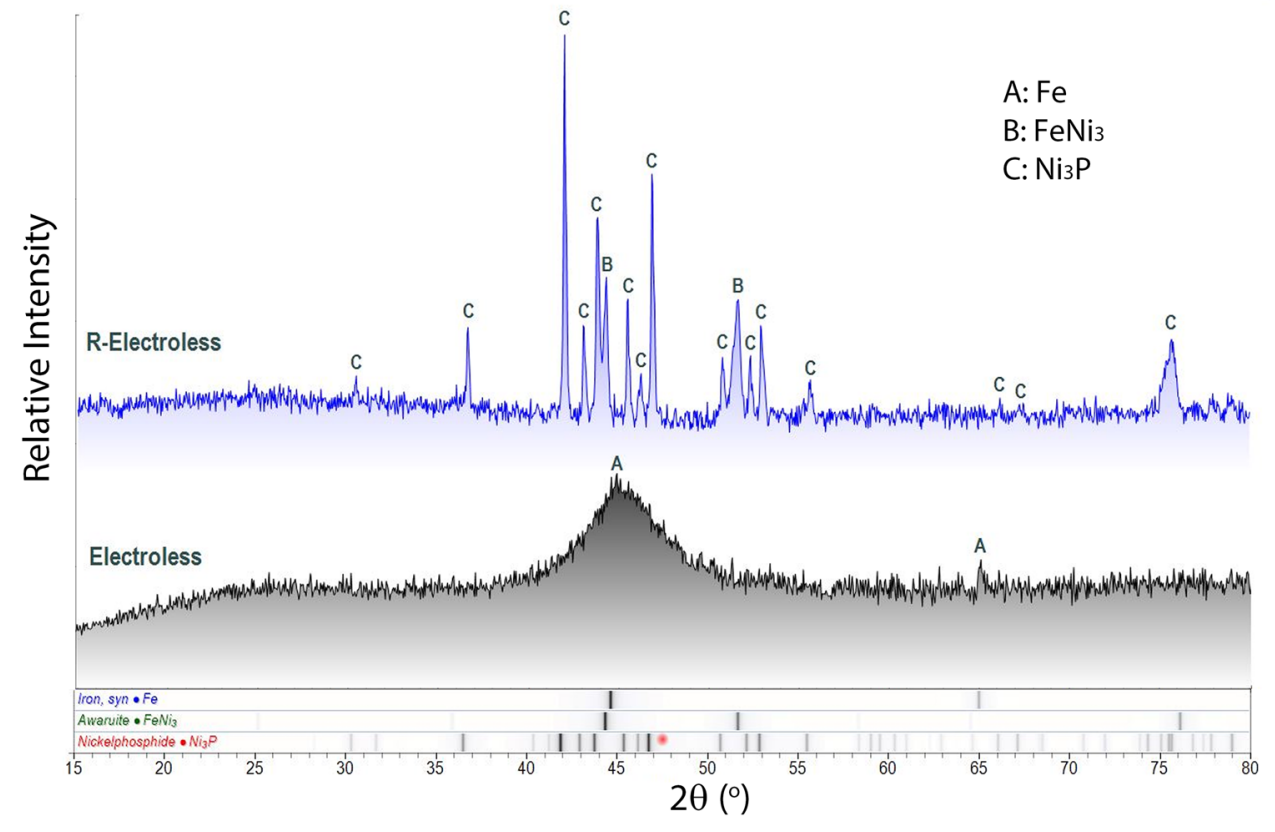

the dark spots, and (3) nickel diffuses $\sim 10 \mu \mathrm{m}$ into the AISI 430 alloy. The EDS elemental maps in Fig. 6 show that: (1) chromium, manganese, and oxygen overlap at the dark spots, and (2) nickel overlaps with phosphorous at the interaction layer. The EDS analyzes reveal that the dark phases are manganese doped chromium oxide and the interaction layer is the solid solution of nickel and phosphorous. Most of the $\mathrm{Ni}-\mathrm{Cu}$ topcoat spalled off during metallographic sample preparation leading to non-uniform polishing and iron detection in the top coat.

$\mathrm{Ni}_{3} \mathrm{P}$ and $\mathrm{FeNi}_{3}$ intermetallic compounds are detected from XRD analysis in Fig. $3 . \mathrm{Ni}_{3} \mathrm{P}$ forms due to the crystallization of amorphous $\mathrm{Ni}-\mathrm{P}$ coating [22]. $\mathrm{FeNi}_{3}$ forms due to interfusion of nickel and iron. The small quantity of chromium oxide, seen from the SEM image, is beyond the XRD detection limit.

\subsection{Oxidation behavior}

Figure 7 shows the weight changes due to isothermal oxidation at $800^{\circ} \mathrm{C}$ in moisture-saturated air of the electroless and R-electroless samples. The oxidation rate is determined (up to $50 \mathrm{~h}$ ) by the following equation:

$\left(\frac{\Delta W}{A}\right)^{2}=k_{p} t$

where $\Delta w$ is the weight change due to oxidation, $\mathrm{A}$ is the surface area, $t$ is time for isothermal oxidation, $k_{p}$ is the oxidation rate $\left(\mathrm{mg}^{2} / \mathrm{cm}^{4} \mathrm{~s}\right)$.

The oxidation rate R-electroless $\left(8.93 \times 10^{-6} \mathrm{mg}^{2} /\right.$ $\left.\mathrm{cm}^{4} \mathrm{~s}\right)$ is lower than electroless $\left(2.35 \times 10^{-5} \mathrm{mg}^{2} / \mathrm{cm}^{4} \mathrm{~s}\right)$ sample. The oxidation rate of uncoated AISI 430 alloy $\left(6.08 \times 10^{-5} \mathrm{mg}^{2} / \mathrm{cm}^{4} \mathrm{~s}\right)$ [27] is higher than that for both the electroless and R-electroless samples.

\subsection{Microstructure and XRD analysis}

\subsubsection{Electroless}

The oxide layer of the electroless coating (Fig. 8a) contains equiaxed grains and bright spots (marked as 1 ) as well. The average size of the equiaxed grains (Fig. 8b) is $5.29 \pm 1.44 \mu \mathrm{m}$. These grains consist of $28.4 \pm 2.3 \mathrm{Fe}$, $11.6 \pm 0.7 \mathrm{Ni}, 0.1 \pm 0.0 \mathrm{P}$, and $58.5 \pm 3.4 \mathrm{O}$. The bright grain (arrow marked) shows manganese $(1.1 \pm 0.1)$ presence. The bright spots (spot 1) consists of $2.6 \pm 0.2 \mathrm{Fe}, 0.1 \pm 0.0 \mathrm{Cr}$, $41.5 \pm 2.6 \mathrm{Ni}$, and $55.6 \pm 2.7 \mathrm{O}$. The average size of the equiaxed grains (Fig. 8c) in the bright spots is $1.92 \pm 1.40 \mu \mathrm{m}$. Pores are observed at the boundaries (marked with dotted boundary in Fig. 8c) between the equiaxed grains in bulk and at the bright spots (1).

Figure $8 \mathrm{~d}$ shows the cross-sectional microstructure of the oxidized electroless sample. Several distinct features along with pores and cracks are observed in the $\sim 65 \mu \mathrm{m}$ thick oxide layer. Table 2 shows the elemental composition determined from EDS spot analysis. The sublayers in the oxide layer can be described, according to compositional variation, as follows: (i) silicon and oxygen -rich dark spots at the oxide layer/AISI430 interface (marked with gray arrow), (ii) $\sim 8 \mathrm{~m}$ thick chromium and oxygen -rich layer 1, (iii) chromium, nickel, and oxygen -rich layer 2, (iii) nickel and oxygen -rich bright spots (spots 4 ) in a $\sim 12 \mu \mathrm{m}$ thick chromium, iron, and oxygen -rich gray layer 3 , (iv) $\sim 5 \mu \mathrm{m}$ 


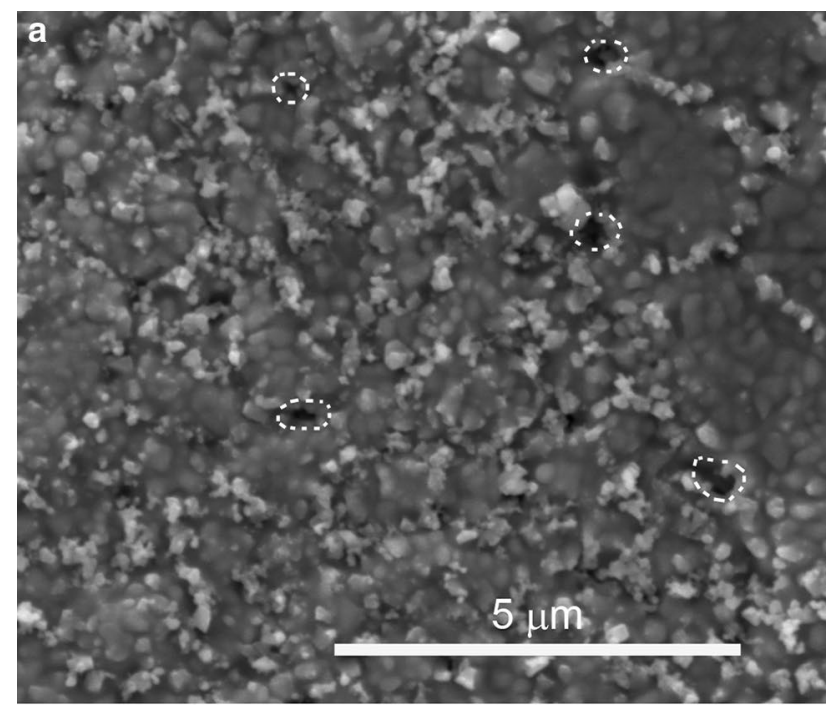

Fig. 6 EDS elemental maps of R-electroless cross-section
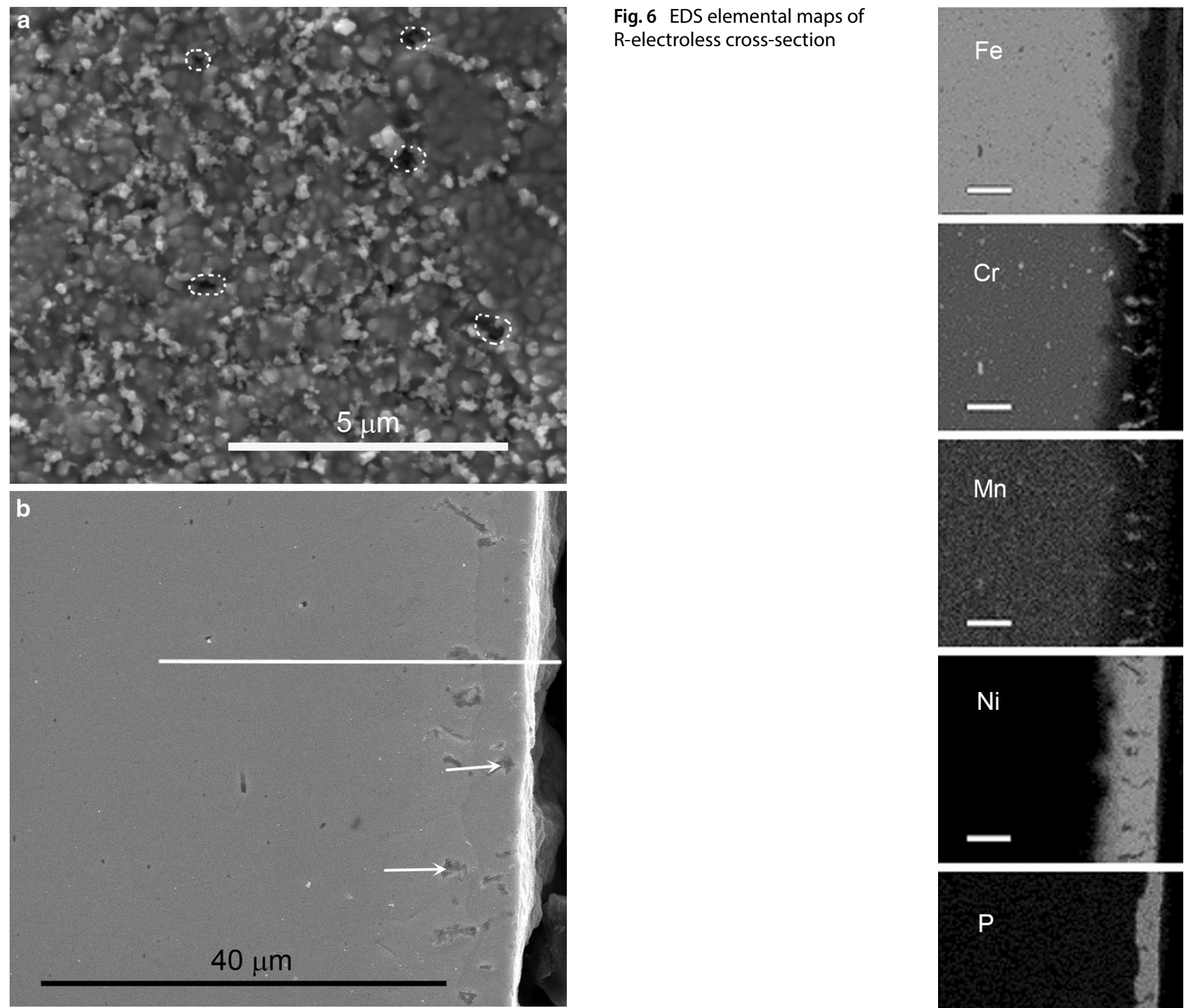
tion. Solid horizontal line in b corresponds to the EDS line scan in Fig. 5
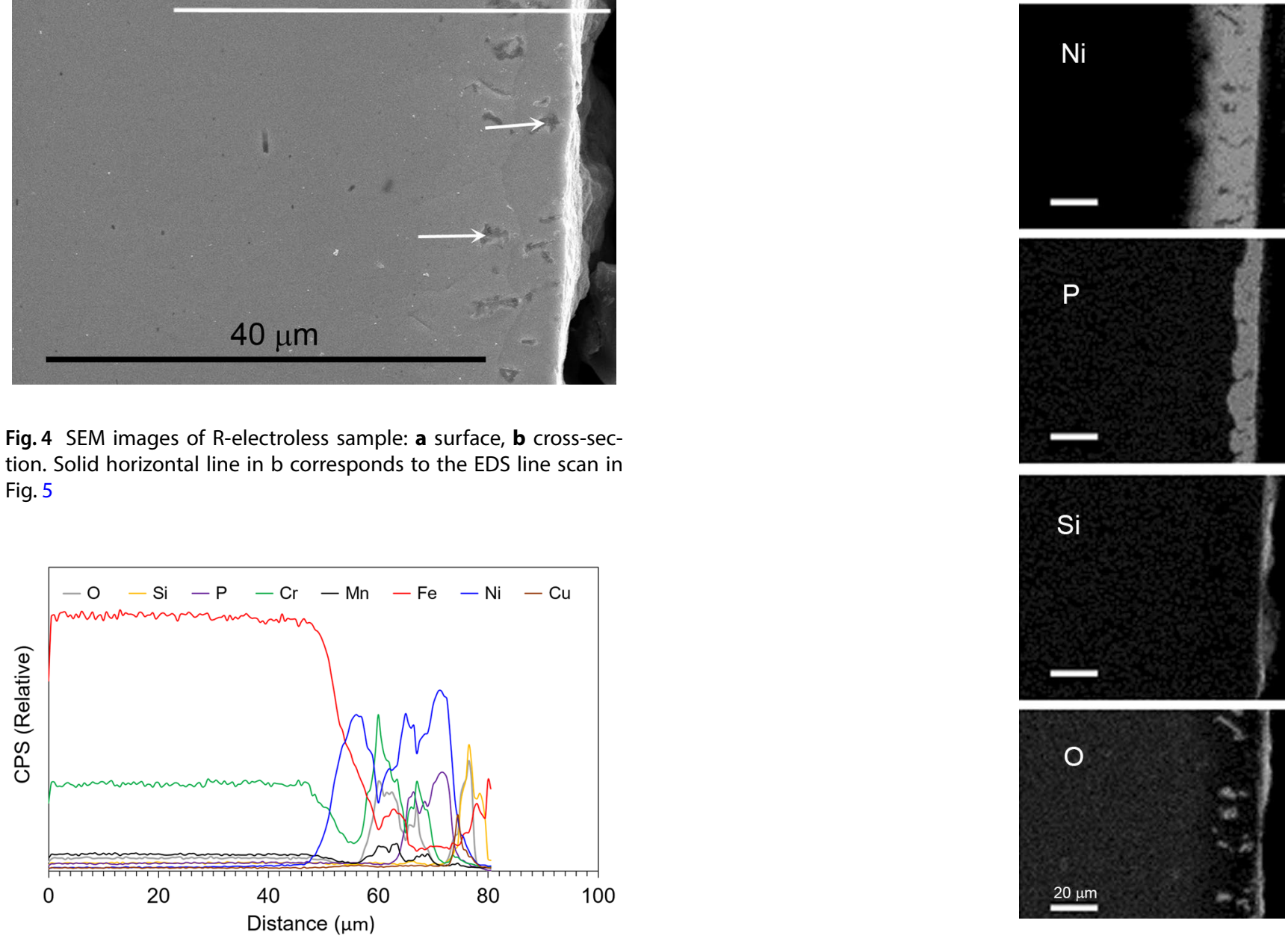

Fig. 5 EDS line scan profile of R-electroless cross-section 


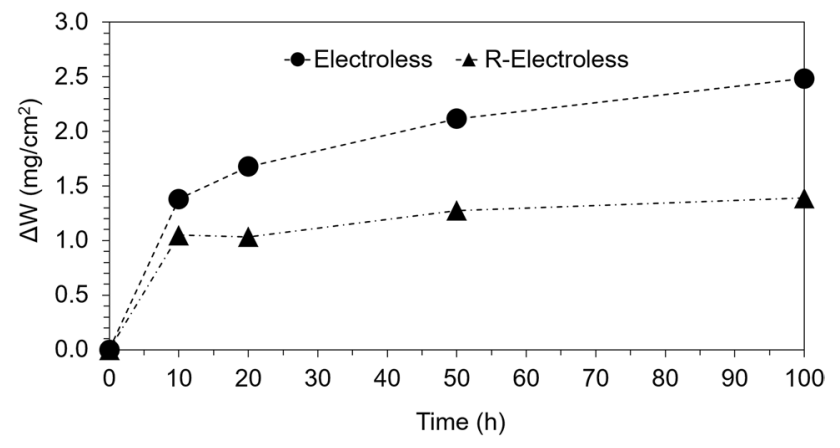

Fig. 7 Weight change versus time for oxidation of the electroless and R-electroless samples at $800{ }^{\circ} \mathrm{C}$ in moisture-saturated air

thick phosphorous, iron, and oxygen -rich dark layer 5, (v) $~ 17 \mu \mathrm{m}$ iron, nickel, and oxygen -rich bright layer 6 , (vi) $10 \mu \mathrm{m}$ thick iron and oxygen -rich gray layer 7 , and outermost iron, nickel and oxygen -rich layer 8 of $\sim 6 \mu \mathrm{m}$ thickness with scattered bright phases (marked with white arrow).

Figure 9 shows the elemental concentration profile of the oxidized electroless sample. Various compounds in the oxide layer can reasonably be assigned by comparing the spot analysis and line scan profile, and $\mathrm{Cr}-\mathrm{Fe}-\mathrm{O}$ and $\mathrm{Fe}-\mathrm{Ni}-\mathrm{O}$ phase diagrams [28-31]. The partial pressure of oxygen $\left(P_{\mathrm{O}_{2}}\right)$ decreases across the oxide layer from the oxide/gas interface to the AISI 430/oxide interface. The assigned compounds in the oxide layer may differ from XRD analysis since the actual $\mathrm{PO}_{2}$ in these layers is unknown and EDS provides only elemental composition.

Increase in silicon and oxygen concentration at the oxide layer/substrate interface suggests that the dark spots are $\mathrm{SiO}_{2}$. Similarly, increased chromium and manganese content between the dark spots and layer 1 indicates the presence of $\mathrm{Mn}$-doped $\mathrm{Cr}_{2} \mathrm{O}_{3}$. Compositional variation is observed in layer 1 . Increase in iron content along with decreased chromium is observed in the first
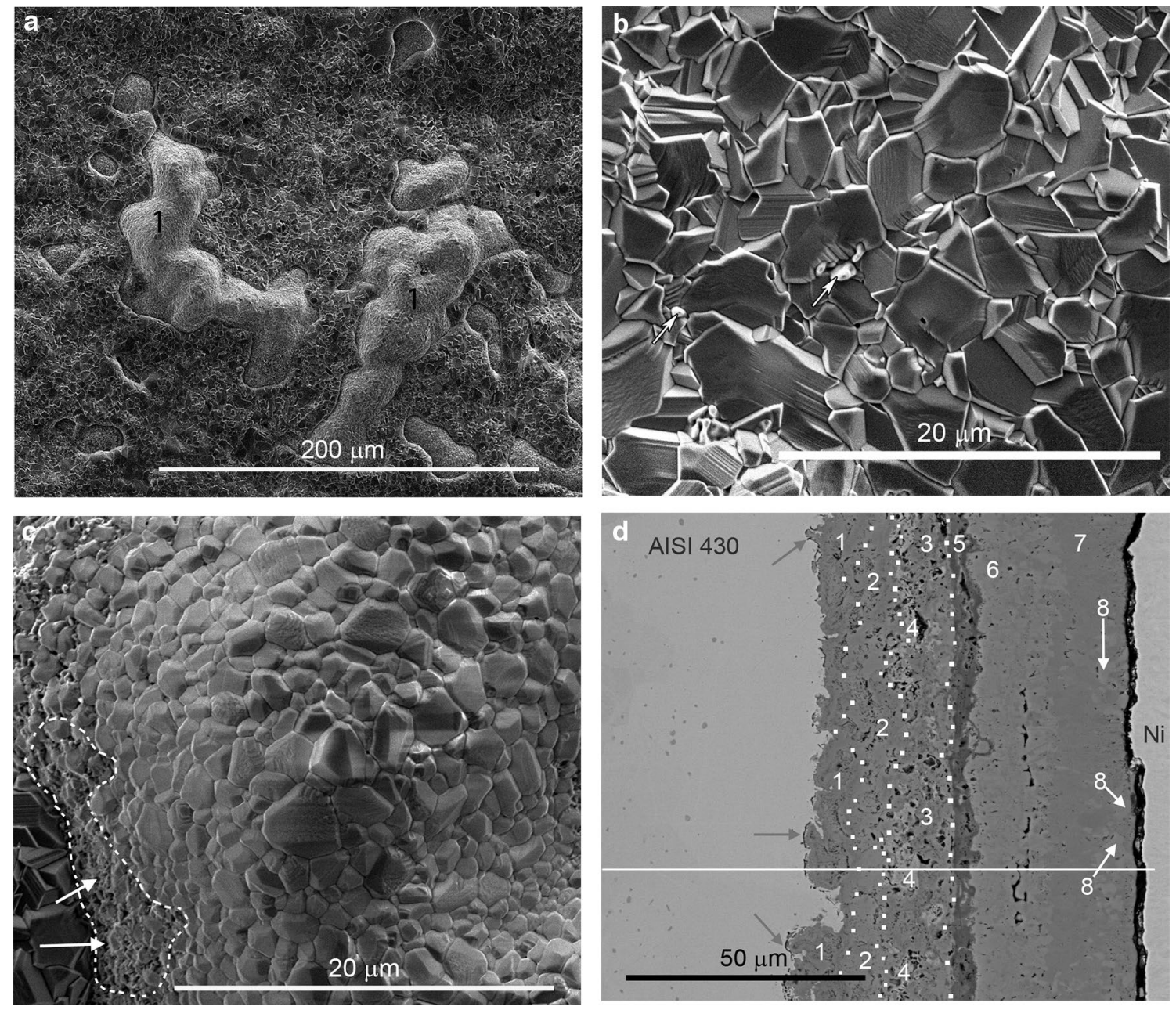

Fig. 8 SEM images of the oxidized electroless sample: a surface, $\mathbf{b}$ higher magnification of surface, $\mathbf{c}$ higher magnification of bright spots (marked as 1) in a, $\mathbf{d}$ cross-section. Dotted lines guide the boundaries. Solid horizontal line in $\mathbf{d}$ corresponds to the EDS line scan in Fig. 9

\section{SN Applied Sciences}


Table 2 Elemental composition (at\%), determined by EDS spot analysis, across the oxide layer of the oxidized electroless sample

\begin{tabular}{lllllllll}
\hline Elements & 1 & 2 & 3 & 4 & 5 & 6 & 7 & 8 \\
\hline $\mathrm{O}$ & $49.0 \pm 1.5$ & $49.4 \pm 0.4$ & $53.0 \pm 4.6$ & $44.4 \pm 0.8$ & $57.8 \pm 0.8$ & $62.2 \pm 0.6$ & $55.1 \pm 0.4$ & $54.8 \pm 0.4$ \\
$\mathrm{Si}$ & $0.8 \pm 0.3$ & $0.5 \pm 0.1$ & $0.5 \pm 0.2$ & $0.4 \pm 0.2$ & $0.3 \pm 0.3$ & 0 & 0 & 0 \\
$\mathrm{P}$ & 0 & $0.2 \pm 0.1$ & $0.8 \pm 0.7$ & $0.5 \pm 0.3$ & $10.7 \pm 2.3$ & 0 & 0 & 0 \\
$\mathrm{Cr}$ & $22.2 \pm 4.0$ & $12.3 \pm 3.2$ & $18.9 \pm 4.9$ & $3.7 \pm 1.4$ & $1.0 \pm 0.5$ & $0.4 \pm 0.2$ & 0 & 0 \\
$\mathrm{Mn}$ & 0 & $0.3 \pm 0.2$ & $0.4 \pm 0.2$ & $0.1 \pm 0.0$ & $0.8 \pm 0.7$ & 0 & $0.3 \pm 0.2$ & 0 \\
$\mathrm{Fe}$ & $27.7 \pm 2.3$ & $22.8 \pm 2.8$ & $15.6 \pm 1.1$ & $4.1 \pm 1.5$ & $22.9 \pm 3.0$ & $34.3 \pm 1.2$ & $44.7 \pm 1.7$ & $33.5 \pm 1.2$ \\
$\mathrm{Ni}$ & $0.3 \pm 0.1$ & $14.5 \pm 0.9$ & $10.8 \pm 0.8$ & $46.7 \pm 2.7$ & $7.6 \pm 3.8$ & $13.2 \pm 1.3$ & 0 \\
Possible compounds & $(\mathrm{Fe}, \mathrm{Cr})_{1-\mathrm{x}} \mathrm{O}, \mathrm{FeCr}_{2} \mathrm{O} 4$ & $\mathrm{Fe}(\mathrm{Ni}, \mathrm{Cr})_{2} \mathrm{O}_{4}$ & $\left(\mathrm{Fe}, \mathrm{Ni}_{2}\right) \mathrm{Cr}_{2} \mathrm{O}_{4}$ & $\mathrm{NiO}$ & $\mathrm{Ni}_{x} \mathrm{P}$ & $\mathrm{Fe}_{2} \mathrm{NiO}_{4}$ & $\mathrm{Fe}_{3} \mathrm{O}_{4}$ & $\mathrm{Fe}_{2} \mathrm{NiO}_{4}, \mathrm{Fe}_{3} \mathrm{O}_{4}$ \\
\hline
\end{tabular}

The numbers indicate corresponding spots in Fig. $8 \mathrm{~d}$

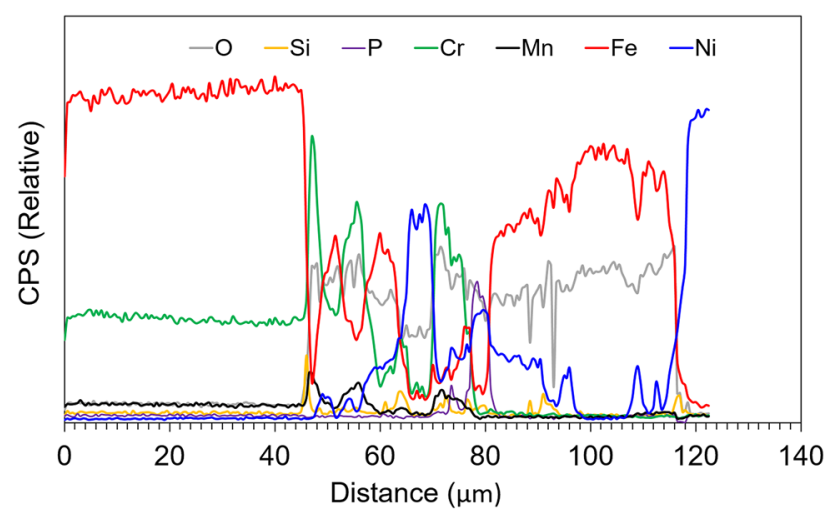

Fig. 9 EDS line scan profile of oxidized electroless sample crosssection

part while iron decreases but chromium and manganese increase in the remaining part. $(\mathrm{Fe}, \mathrm{Cr})_{1-\mathrm{x}} \mathrm{O}$ (halite) and $\mathrm{FeCr}_{2} \mathrm{O}_{4}$ spinel in the first part and $\mathrm{FeCr}_{2} \mathrm{O}_{4}$ spinel in the remaining part are expected according to $\mathrm{Cr}-\mathrm{Fe}-\mathrm{O}$ phase diagram considering the $\sim 0.54 \mathrm{~mol}$ fraction of iron and low $\mathrm{PO}_{2}\left(<10^{-15}\right.$ bar $)$ in layer $1[29,30]$. Iron content again increases in layer 2 while chromium content decreases and nickel content increases, indicating halite and $\mathrm{Fe}(\mathrm{Ni}, \mathrm{Cr})_{2} \mathrm{O}_{4}$ spinel presence. Chromium content is higher than nickel and iron in layer 3 , indicating $(\mathrm{Fe}, \mathrm{Ni}) \mathrm{Cr}_{2} \mathrm{O}_{4}$ spinel presence. Phosphorous tends to increase in this layer. The bright phases (spot 4) are NiO. Higher concentration of nickel and phosphorus indicates $\mathrm{Ni}_{\mathrm{x}} \mathrm{P}$ presence in layer 5 . Iron content increases and nickel content decreases in layer 6 , suggesting $\mathrm{Fe}_{2} \mathrm{NiO}_{4}$ presence. Negligible nickel content in layer 7 suggests $\mathrm{Fe}_{3} \mathrm{O}_{4}$ presence. Slight increase in nickel content in layer 8 suggests the presence of $\mathrm{Fe}_{2} \mathrm{NiO}_{4}$ embedded in a $\mathrm{Fe}_{3} \mathrm{O}_{4}$ matrix. Considering nickel mole fraction, $\mathrm{Fe}-\mathrm{Ni}-\mathrm{O}$ phase [31] diagram suggests $(\mathrm{Fe}, \mathrm{Ni})_{3} \mathrm{O}_{4}$ spinel and $\mathrm{Fe}_{2} \mathrm{O}_{3}$ presence in layers 6 and 8 . However, the $\mathrm{Fe}$, $\mathrm{Ni}$, and $\mathrm{O}$ atomic ratio matches well with $\mathrm{Fe}_{2} \mathrm{NiO}_{4}$ spinel, consistent with another report [28]. Juxtaposition of the EDS elemental maps in Fig. 10a compliments the EDS line scan profile and spot analyzes. Scattered silicon presence in the oxide layer is noted. Resin impregnation in the pores during metallographic sample preparation is the source of silicon.

$\mathrm{Fe}_{2} \mathrm{NiO}_{4}, \mathrm{Fe}_{2.67} \mathrm{O}_{4}$, and $\mathrm{Fe}_{2} \mathrm{O}_{3}$ compounds are detected from the XRD analysis in Fig. 11. The peak positions corresponds to the diffracted planes for these compounds overlap in the XRD plot. Other plausible compounds, determined from EDS analysis, such as $\mathrm{Cr}_{2} \mathrm{O}_{3}, \mathrm{FeCr}_{2} \mathrm{O}_{4}$, $(\mathrm{Fe}, \mathrm{Ni})$ $\mathrm{Cr}_{2} \mathrm{O}_{4}, \mathrm{Ni}_{x} \mathrm{P}, \mathrm{NiO}$ are not detected since these compounds are beyond the $\mathrm{X}$-ray penetration limit of $\sim 25 \mu \mathrm{m}$ depth into the oxide layer [32].

The oxidation of the electroless AISI 430 occurs in multiple steps as discussed below and shown in a schematic diagram in Fig. 12. First, amorphous Ni-P crystallizes above $400^{\circ} \mathrm{C}$ into $\mathrm{Ni}_{3} \mathrm{P}$ intermetallic compound and nickel oxide (NiO) $[12,22,33]$. NiO, a p-type oxide, grows outward due to $\mathrm{Ni}^{2+}$ diffusion through cation vacancies $\left(V_{\mathrm{Ni}}^{\prime \prime}\right)$ in the oxide grain and grain boundaries. At $800^{\circ} \mathrm{C}$ and $1 \mathrm{~atm} . \mathrm{PO}_{2}$, grain boundary diffusivity of nickel $\left(\sim 2.6 \times 10^{-9} \mathrm{~cm}^{2} / \mathrm{s}\right.$ assuming $0.5 \mathrm{~nm}$ thick grain boundary) in the oxide is approximately five orders of magnitude higher than the lattice diffusion coefficient $\left(2.1 \times 10^{-14} \mathrm{~cm}^{2} / \mathrm{s}\right)$ [34]. Nickel diffusion through the grain boundaries controls outward growth of $\mathrm{NiO}$ associated with voids/pores at $\mathrm{Ni}_{3} \mathrm{P} / \mathrm{NiO}$ interface [34-36].

Second, oxygen diffuses inward into the AISI 430 substrate through the oxide grains, grain boundaries, and voids/pores and cracks in the oxide. Diffusion of molecular oxygen gas through pores is much higher than oxygen diffusion through grain and grain boundaries. Oxygen diffusion triggers $\mathrm{Cr}_{2} \mathrm{O}_{3}$ formation by internal oxidation of AISI 430. $\mathrm{Cr}_{2} \mathrm{O}_{3}$, a p-type oxide, grows externally due to $\mathrm{Cr}^{3+}$ diffusion through the cation vacancy $\left(V_{C r}^{\prime \prime \prime}\right) . \mathrm{Cr}^{3+}$ diffuses and dissolves into $\mathrm{NiO}$, and forms $\mathrm{NiCr}_{2} \mathrm{O}_{4}$ spinel. Subsequently, chromium concentration at the AISI 430 adjacent to $\mathrm{Cr}_{2} \mathrm{O}_{3}$ decreases $(\sim 14.7 \pm 0.4)$ as confirmed by EDS spot analysis. $\mathrm{Mn}^{\mathrm{n}+}$ and $\mathrm{Fe}^{\mathrm{n}+}(\mathrm{n}=2$ or 3) cations diffuse and dissolve into the $\mathrm{Cr}_{2} \mathrm{O}_{3}$ layer. Diffusivity of the cations in $\mathrm{Cr}_{2} \mathrm{O}_{3}$ decreases in the order 
Fig. 10 EDS elemental maps

of oxidized $\mathbf{a}$ electroless and $\mathbf{b}$

R-electroless cross-sections
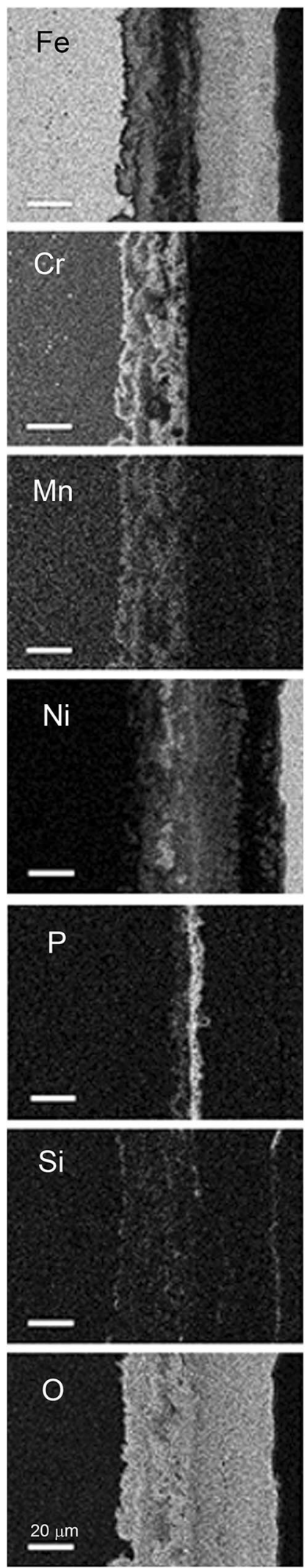

a
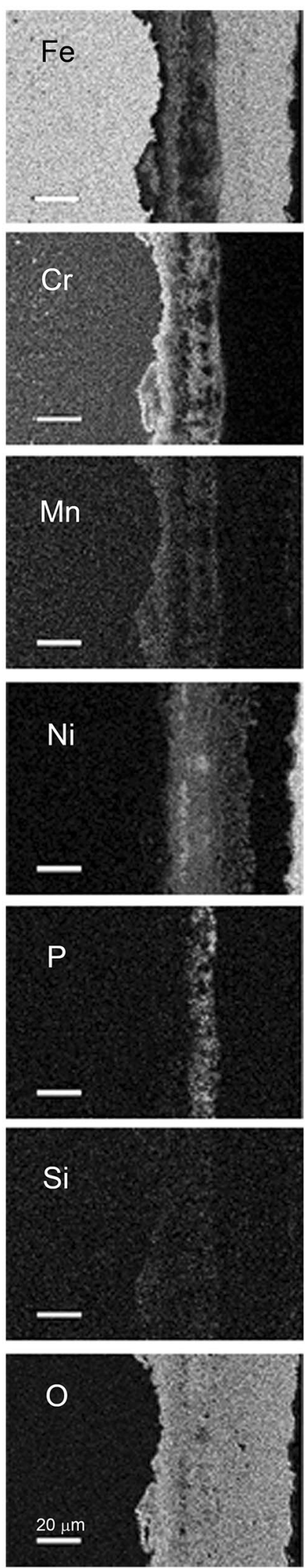

b 
Fig. 11 XRD plots of oxidized electroless and R-electroless samples
Fig. 12 Schematic diagram to illustrate different oxidation stages (I-V) for electroless sample. See text for detail. Arabic numbers correspond to Fig. $8 \mathrm{~d}$ and Table 2
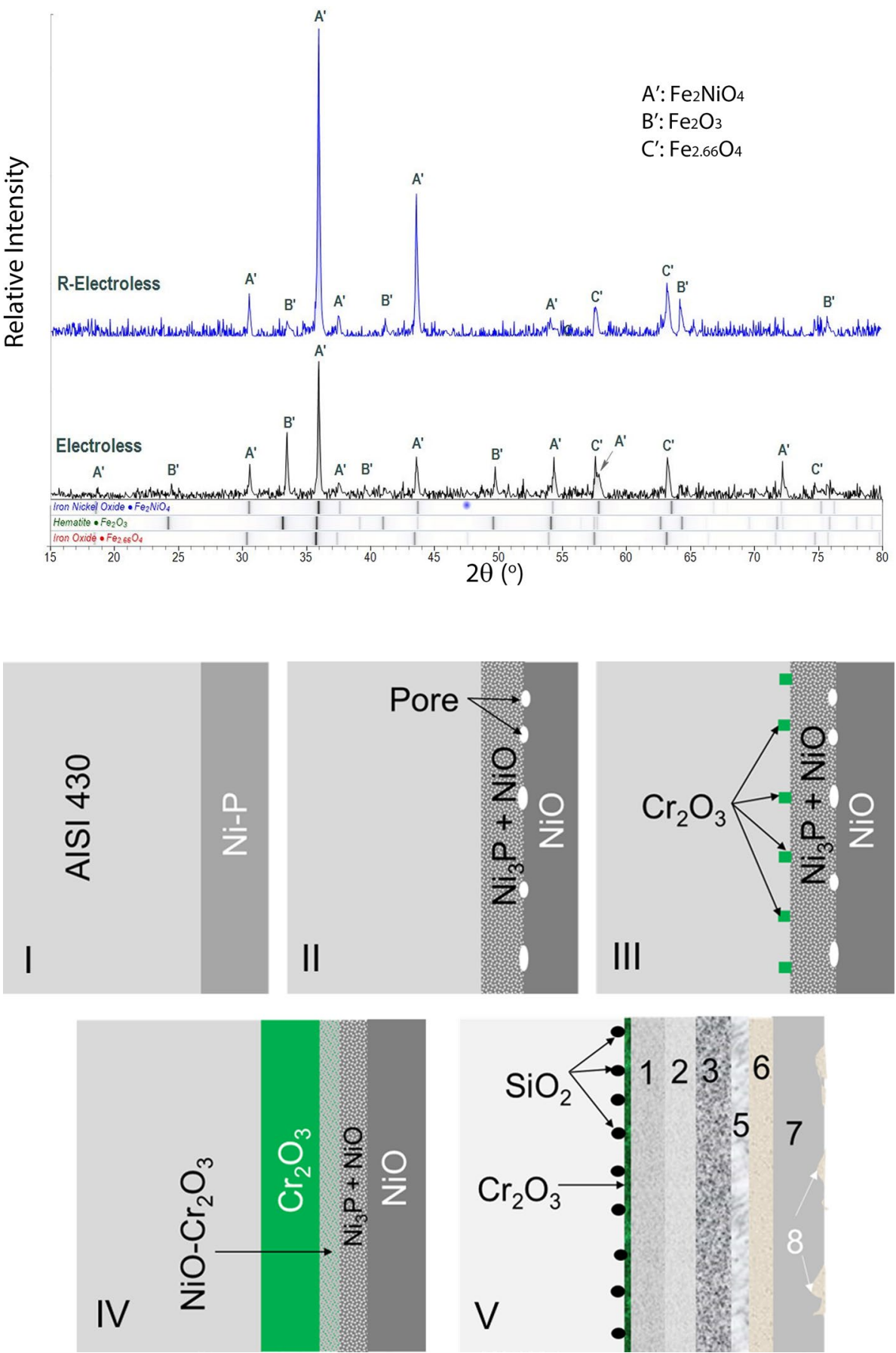

of $\mathrm{D}_{\mathrm{Cr}}<\mathrm{D}_{\mathrm{Ni}}<\mathrm{D}_{\mathrm{Fe}}<\mathrm{D}_{\mathrm{Mn}}$ [37]. $\mathrm{Mn}^{\mathrm{n}+}$ dissolves into the $\mathrm{Cr}_{2} \mathrm{O}_{3}$ as supported by overlapping chromium and manganese maps (Fig. 10a). $\mathrm{Fe}^{\mathrm{n}+}$ continues to diffuse into the $\mathrm{Cr}_{2} \mathrm{O}_{3}$ due to higher concentration and forms $(\mathrm{Fe}, \mathrm{Cr})_{1-\mathrm{x}} \mathrm{O}$ and $\mathrm{FeCr}_{2} \mathrm{O}_{4}$ phases, suggesting the absence of $\mathrm{MnCr}_{2} \mathrm{O}_{4}$ spinel since its presence should retard interdiffusion of ions. Simultaneously, $\mathrm{Ni}^{2+}$ also diffuses towards the substrate due to chemical potential gradient of nickel and dissolves into the $\mathrm{FeCr}_{2} \mathrm{O}_{4}$ spinel. As a result, $(\mathrm{Fe}, \mathrm{Cr})_{1-\mathrm{x}} \mathrm{O}$ and $(\mathrm{Fe}, \mathrm{Ni}) \mathrm{Cr}_{2} \mathrm{O}_{4}$ are formed in layer 2. Both $\mathrm{Fe}^{\mathrm{n}+}$ and
$\mathrm{Cr}^{3+}$ dissolve into $\mathrm{NiO}$ lattice and form $(\mathrm{Fe}, \mathrm{Ni}) \mathrm{Cr}_{2} \mathrm{O}_{4}$ or $(\mathrm{Fe}, \mathrm{Ni}, \mathrm{Cr})_{\mathrm{x}} \mathrm{O}_{4}$ spinel in layer 3.

Iron diffuses through $\mathrm{Ni}-\mathrm{P}$ layer into $\mathrm{NiO}$, but manganese and chromium diffusion is not observed. Approximate 1:1 Ni and $P$ atomic ratio in the layer 5 (as seen from EDS spot analysis) suggests NiP presence, which exists above $800{ }^{\circ} \mathrm{C}$ according to $\mathrm{Ni}-\mathrm{P}$ phase diagram [38]. Iron diffusion into the $\mathrm{Ni}-\mathrm{P}$ layer likely promotes NiP formation at $\leq 800^{\circ} \mathrm{C}$, similar to the observation for Ni-P-Re crystallization. Decomposition of $\mathrm{Ni}_{3} \mathrm{P}$ into $\mathrm{Ni}_{12} \mathrm{P}_{5}, \mathrm{Ni}_{2} \mathrm{P}$ and $\mathrm{NiO}$ at 
$>500{ }^{\circ} \mathrm{C}$ has been reported [22]. Overlapping iron, nickel, and phosphorous maps indicates the presence of $\mathrm{Fe}_{x} \mathrm{P}$ compound. Oxygen presence in the layer 5 suggests also the presence of oxide phases such as $\mathrm{Fe}_{2} \mathrm{O}_{3}$ and $(\mathrm{Fe}, \mathrm{Ni}) \mathrm{O}$ [31]. Lower phosphorus content in the oxide layer than the as-received sample is noted. Sublimation of $\mathrm{P}_{2} \mathrm{O}_{5}$ during $\mathrm{Ni}_{3} \mathrm{P}$ oxidation [39] attributes to lower the phosphorous content, supported by pores in layer 5 .

Third, $\mathrm{Fe}^{\mathrm{n}+}$ continues to diffuse through the cation vacancies $\left(V_{\mathrm{Ni}}^{\prime \prime}\right)$ in $\mathrm{NiO}$ grains and grain boundaries, dissolves into the $\mathrm{NiO}$ lattice, and forms $\mathrm{Fe}_{2} \mathrm{NiO}_{4}$ spinel. Diffusivity of iron in $\mathrm{NiO}$ is higher than the self-diffusivity of nickel [40], leading to iron oxide formation. $\mathrm{Fe}_{3} \mathrm{O}_{4}$, a p-type oxide, prefers to form first because of its higher stability than $\mathrm{FeO}$ and $\mathrm{Fe}_{2} \mathrm{O}_{3}$ [41]. $\mathrm{Fe}^{2+}$ diffusion into the $\mathrm{Fe}_{3} \mathrm{O}_{4}$ causes $\mathrm{Fe}_{2.94} \mathrm{O}_{3}$ and $\mathrm{Fe}_{2} \mathrm{O}_{3}$ formation [42]. Another study in literature reports $\left(\mathrm{Fe}, \mathrm{Ni}_{3} \mathrm{O}_{4}\right.$ and $\mathrm{Fe}_{2} \mathrm{O}_{3}$ formation [19]. However, $\mathrm{Fe}_{2} \mathrm{NiO}_{4}$ is detected by XRD, consistent with another study [28]. In parallel, nickel also diffuses inward due to chemical potential gradient across the oxide layer. Nickel does not diffuse beyond layer 2 since $\mathrm{D}_{\mathrm{Cr}}$ in $\mathrm{NiO}>\mathrm{D}_{\mathrm{Ni}}$ in $\mathrm{Cr}_{2} \mathrm{O}_{3}[37,40]$. Difference in diffusivity of the cations generate vacancies, which coalesce into voids. Difference in the thermal expansion co-efficient between the compounds also generate pores and voids to accommodate thermal stress [42]. For instance, the thermal expansion coefficient of $\mathrm{NiFe}_{2} \mathrm{O}_{4}, \mathrm{Fe}_{2} \mathrm{O}_{3}$ and $\mathrm{Fe}_{3} \mathrm{O}_{4}$ are, respectively, $\sim 10.8 \times 10^{-6} /{ }^{\circ} \mathrm{C}[43], \sim 12.0 \times 10^{-6} /{ }^{\circ} \mathrm{C}$, and $15.0 \times 10^{-6} /{ }^{\circ} \mathrm{C}$ [44].

Fourth, AISI 430 alloy adjacent to the oxide layer is chromium deficient $(79.2 \pm 1.1 \mathrm{Fe}, 14.7 \pm 0.4 \mathrm{Cr}, 0.5 \pm 0.1 \mathrm{Mn}$, $0.5 \pm 0.2 \mathrm{Ni}, 0.2 \pm 0.1 \mathrm{P}, 0.3 \pm 0.2 \mathrm{Si}, 4.0 \pm 0.3 \mathrm{O}$ ). $\mathrm{SiO}_{2}$ forms by internal oxidation due to inward oxygen diffusion and chromium deficiency at the $\mathrm{AISI} 430$ alloy. $\mathrm{SiO}_{2}$ layer acts as a barrier for elemental interdiffusion across the AISI 430/ oxide layer interface and prevents further oxidation [42].

\subsubsection{R-electroless}

The oxide layer of the R-electroless sample (Fig. 13a) contains grains $(31.3 \pm 0.0 \mathrm{Fe}, 0.5 \pm 0.1 \mathrm{Mn}, 10.2 \pm 1.0 \mathrm{Ni}$, and $58.2 \pm 1.2 \mathrm{O})$, and platelets $(30.2 \pm 2.8 \mathrm{Fe}, 0.5 \pm 0.1 \mathrm{Mn}$, $3.2 \pm 0.8 \mathrm{Ni}$, and $66.1 \pm 2.2 \mathrm{O}$ ), and bright spot (marked with arrow in Fig. 13b) at grain boundaries $(26.9 \pm 2.3$ $\mathrm{Fe}, 0.5 \pm 0.1 \mathrm{Mn}, 6.4 \pm 0.9 \mathrm{Ni}$, and $66.3 \pm 2.7 \mathrm{O}$ ). Pores are observed at the grain boundaries for two plausible reasons. $\mathrm{Cr}_{2} \mathrm{O}_{3}$ at the grain boundaries (bright spots in Fig. 4a) in unoxidized R-electoless AISI 430 evaporates as $\mathrm{CrO}_{3}$ and $\mathrm{CrO}_{2}(\mathrm{OH})_{2}$ species [45], supported by the absence of chromium in EDS spot analysis. Molecular oxygen at the voids/ pores preferes diffusion of cations from the $\mathrm{FeNi}_{3}$ intermetallic towards the grain boundaries to form oxides, forming voids at the metal/oxide interface. The voids coalease into large pores to reduce surface energy.

Figure 13c, d show the cross-sectional microstructure of the oxidized R-electroless sample. Several distinct features along with pores and cracks are observed in the $\sim 65 \mu \mathrm{m}$ thick oxide layer. Table 3 shows the elemental composition determined from EDS spot analysis. The sublayers in the oxide layer can be described as follows: (i) silicon and oxygen-rich sporadic dark spots (marked by gray arrow), at the oxide layer/AISI 430 interface (ii) chromium and oxygen-rich thin layer 1 (marked by dotted boundary), (iii) chromium, iron, and oxygen- rich layer 2 , (iii) $\sim 8 \mu \mathrm{m}$ thick iron, chromium, nickel and oxygen -rich bright layer 3, (iv) $12 \mu \mathrm{m}$ thick layer 4 consisting of phosphorous and oxygen -rich gray phases and iron, chromium, nickel and oxygen -rich bright phases, (v) $\sim 15 \mu \mathrm{m}$ thick layer 5 consisting of iron, nickel, and oxygen-rich bright phases in an iron and oxygen-rich gray phase, (vi) iron and oxygen-rich layer 6 of $\sim 17 \mu \mathrm{m}$ thickness, and (vii) an outermost thin layer 7 of iron, nickel and oxygen -rich.

Figure 14 shows the elemental concentration profile of the oxidized R-electroless samples. The compounds in the oxide layer can be assigned by the similar approach used for the oxidized electroless sample. Increase in silicon and oxygen concentration at the oxide layer/substrate interface suggests that the dark spots are $\mathrm{SiO}_{2}$. Similarly, increase in manganese and chromium suggests the presence of manganese doped $\mathrm{Cr}_{2} \mathrm{O}_{3}$ in the layer 1 . Other possible compounds in the oxide layers are listed in the Table 3. Juxtaposition of the EDS elemental maps in Fig. 10b compliment the plausible phases identified from EDS spot analysis and line scan profile.

$\mathrm{Fe}_{2} \mathrm{NiO}_{4}, \mathrm{Fe}_{2.67} \mathrm{O}_{4}$, and $\mathrm{Fe}_{2} \mathrm{O}_{3}$ compounds are detected from the XRD analysis. The peak positions corresponds to the diffracted planes for these compounds overlap in the XRD plot. Other compounds such as $\mathrm{Cr}_{2} \mathrm{O}_{3}, \mathrm{FeCr}_{2} \mathrm{O}_{4}$, $(\mathrm{Fe}, \mathrm{Cr})_{1-\mathrm{x}} \mathrm{O},(\mathrm{Fe}, \mathrm{Ni}) \mathrm{Cr}_{2} \mathrm{O}_{4},(\mathrm{Ni}, \mathrm{Fe}) \mathrm{O}$ are not detected since these compounds are beyond the $\mathrm{X}$-ray penetration limit of $\sim 25 \mu \mathrm{m}$ depth into the oxide layer.

There are similarities and distinct differences between the oxide layers of the electroless and R-electroless samples. The sublayers between the AISI 430 and the phosphorous containing layer are almost same for both the samples. Iron oxide layer is also overserved for both the samples. The phosphorous containing layer (layer 4 in Fig. 13c) is thicker and more porous for the R-electroless sample compared to the electroless sample (layer 5 in Fig. 8 d). $\mathrm{Ni}_{x} \mathrm{P}$ and $\mathrm{FeCr}_{2} \mathrm{O}_{4}$ phases are likely present as seen from the overlapping of nickel and phosphorous maps and elemental iron and chromium maps (Fig. 10b). $\mathrm{NiFe}_{2} \mathrm{O}_{4}$ spinel embedded in iron oxide is observed in layer 5 of R-electroless sample unlike a continuous $\mathrm{NiFe}_{2} \mathrm{O}_{4}$ spinel in layer 6 of electroless sample. In the outermost layer, $\mathrm{NiFe}_{2} \mathrm{O}_{4}$ 

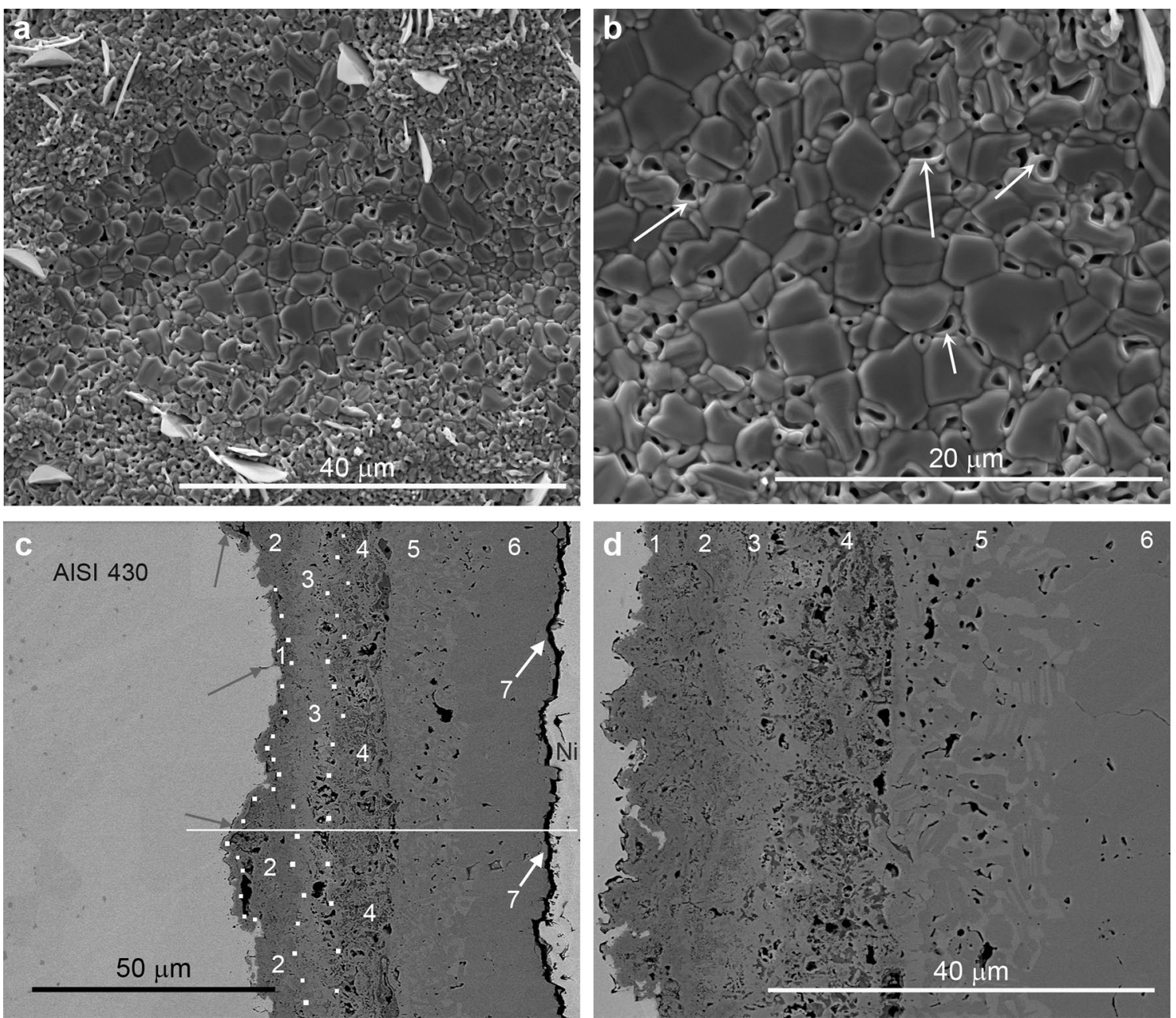

Fig. 13 SEM images of the oxidized R-electroless sample: a surface, $\mathbf{b}$ higher magnification of surface image, $\mathbf{c}$ cross-section, $\mathbf{d}$ higher magnification of cross-sectional image. Solid horizontal line in c corresponds to the EDS line scan in Fig. 14

Table 3 Elemental composition (at\%), determined by EDS spot analysis, across the oxide layer of the oxidized R-electroless sample

\begin{tabular}{|c|c|c|c|c|c|c|c|c|}
\hline Elements & 1 & 2 & 3 & 4 (gray) & 4 (bright) & 5 & 6 & 7 \\
\hline $\mathrm{O}$ & $41.0 \pm 1.9$ & $39.8 \pm 1.3$ & $42.8 \pm 0.8$ & $49.3 \pm 5.2$ & $45.3 \pm 2.1$ & $52.4 \pm 0.8$ & $52.5 \pm 1.6$ & $58.7 \pm 3.4$ \\
\hline $\mathrm{Si}$ & $2.0 \pm 0.4$ & $2.7 \pm 1.5$ & $1.2 \pm 0.1$ & 1.1 & $1.5 \pm 0.4$ & 0.7 & 0 & $1.1 \pm 0.1$ \\
\hline$P$ & 0 & 0 & 0.9 & $11.6 \pm 5.1$ & $3.3 \pm 1.8$ & 0 & 0 & 0 \\
\hline $\mathrm{Cr}$ & $47.6 \pm 4.4$ & $29.6 \pm 15.0$ & $15.3 \pm 2.6$ & $8.8 \pm 9.0$ & $18.7 \pm 6.4$ & $0.8 \pm 0.4$ & $1.9 \pm 1.8$ & 0 \\
\hline $\mathrm{Mn}$ & $1.2 \pm 0.2$ & 0 & 0 & $0.4 \pm 0.2$ & $0.1 \pm 0.1$ & $0.3 \pm 0.3$ & 0 & $2.0 \pm 0.1$ \\
\hline $\mathrm{Fe}$ & $8.7 \pm 4.4$ & $26.9 \pm 14.8$ & $24.9 \pm 2.4$ & $13.4 \pm 1.5$ & $15.6 \pm 5.5$ & $36.4 \pm 2.9$ & $43.3 \pm 1.1$ & $25.8 \pm 1.4$ \\
\hline $\mathrm{Ni}$ & $0.5 \pm 0.4$ & $1.2 \pm 0.6$ & $16.3 \pm 0.8$ & $15.7 \pm 4.1$ & $16.1 \pm 1.1$ & $10.2 \pm 2.5$ & $2.3 \pm 1.1$ & $13.1 \pm 5.1$ \\
\hline $\begin{array}{l}\text { Possible com- } \\
\text { pounds }\end{array}$ & $\mathrm{Cr}_{2} \mathrm{O}_{3}$ & $\begin{array}{c}(\mathrm{Fe}, \mathrm{Cr})_{1-\mathrm{x}} \mathrm{O} \\
\mathrm{FeCr}_{2} \mathrm{O}_{4}\end{array}$ & $(\mathrm{Fe}, \mathrm{Ni}) \mathrm{Cr}_{2} \mathrm{O}_{4}$ & $\begin{array}{l}\mathrm{Ni}_{\mathrm{x}} \mathrm{P}, \\
\mathrm{NiCr}_{2} \mathrm{O}_{4} \\
\mathrm{FeCr}_{2} \mathrm{O}_{4}\end{array}$ & $\mathrm{Fe}_{2} \mathrm{NiO}_{4},(\mathrm{Ni}, \mathrm{Fe}) \mathrm{O}$ & $\mathrm{Fe}_{2} \mathrm{NiO}_{4}, \mathrm{Fe}_{3} \mathrm{O}_{4}$ & $\mathrm{Fe}_{3} \mathrm{O}_{4}$ & $\mathrm{Fe}_{2} \mathrm{NiO}_{4}, \mathrm{Fe}_{3} \mathrm{O}_{4}$ \\
\hline
\end{tabular}

The numbers indicate corresponding spots in Fig. 13c

spinel is distributed in $\mathrm{Fe}_{2} \mathrm{O}_{3}$ for the electroless sample while an almost continuous spinel layer is observed for the R-electroless sample.
The oxidation of R-electroless sample is discussed in terms of the oxidation of $\mathrm{FeNi}_{3}$ intermetallic [46] and $\mathrm{Ni}_{3} \mathrm{P}$ layer and the plausible steps are shown in a schematic 


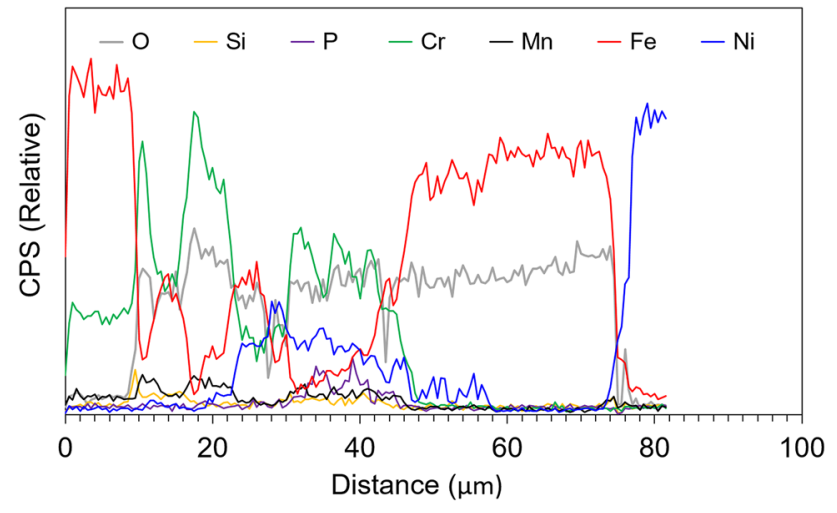

Fig. 14 EDS line scan profile of oxidized R-electroless cross-section
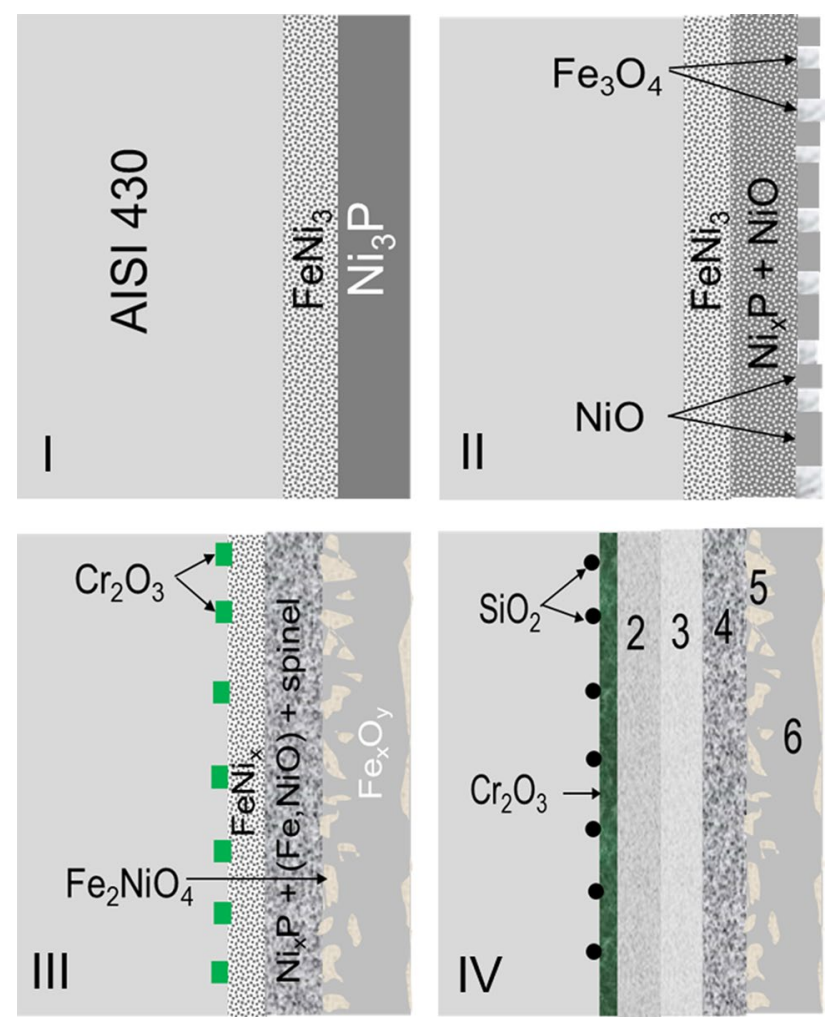

Fig. 15 Schematic diagram to illustrate different oxidation stages (I-IV) for R-electroless sample. See text for detail. Arabic numbers correspond to Fig. $13 \mathrm{c}$ and Table 3

diagram in Fig. 15. Fe is also detected in $\mathrm{Ni}_{3} \mathrm{P}$ layer. $\mathrm{Fe}_{3} \mathrm{O}_{4}$ forms first due to its higher thermodynamic stability than $\mathrm{NiO}[41,42]$. However, iron content in $\mathrm{Ni}_{3} \mathrm{P}$ layer is not sufficient to form a continuous $\mathrm{Fe}_{3} \mathrm{O}_{4}$ oxide layer. $\mathrm{Ni}_{3} \mathrm{P}$ oxidizes into $\mathrm{Ni}_{\mathrm{X}} \mathrm{P}$ phases and $\mathrm{NiO}$ [22]. A mixed $\mathrm{NiO}$ and $\mathrm{Fe}_{3} \mathrm{O}_{4}$ layer forms accompanied with pores at the $\mathrm{Ni}_{3} \mathrm{P}$ and oxide layer interface.

Iron from $\mathrm{FeNi}_{3}$ intermetallic diffuses through $\mathrm{Ni}_{x} \mathrm{P}, \mathrm{NiO}$, and $\mathrm{Fe}_{3} \mathrm{O}_{4}$ [16-19], dissolves into these oxides, and forms
$\mathrm{Fe}_{2} \mathrm{NiO}_{4}$ and $\mathrm{Fe}_{2.67} \mathrm{O}_{4}$. Further diffusion of iron through $\mathrm{Fe}_{2} \mathrm{NiO}_{4}$ and $\mathrm{Fe}_{2.67} \mathrm{O}_{4}$ continues to form $\mathrm{Fe}_{2} \mathrm{O}_{3}$.

$\mathrm{FeNi}_{3}$ becomes iron deficient and $\mathrm{NiO}$ formation starts. $\mathrm{NiO}$ forms solid solution with $\mathrm{Fe}_{3} \mathrm{O}_{4}$ and also forms $\mathrm{NiFe}_{2} \mathrm{O}_{4}$ spinel. Iron and nickel both diffuses through the $\mathrm{Fe}_{3} \mathrm{O}_{4}$ and $\mathrm{NiFe}_{2} \mathrm{O}_{4}$ spinel but diffusivity of iron is higher than nickel [37]. So, iron oxide $\left(\mathrm{Fe}_{2.67} \mathrm{O}_{4}\right.$ and/or $\left.\mathrm{Fe}_{2} \mathrm{O}_{3}\right)$ grows outward.

Similar to the electroless sample, $\mathrm{Cr}_{2} \mathrm{O}_{3}$ forms due to internal oxidation of AISI 430 by inward oxygen diffusion as discussed in the previous section. $\mathrm{FeCr}_{2} \mathrm{O}_{4}(\mathrm{Fe}, \mathrm{Cr})_{1-\mathrm{x}} \mathrm{O}$, $(\mathrm{Fe}, \mathrm{Ni}) \mathrm{Cr}_{2} \mathrm{O}_{4},(\mathrm{Ni}, \mathrm{Fe}) \mathrm{O}$ compounds form by the similar mechanisms as discussed for the electroless sample.

The present study is limited to isothermal oxidation of the electroless and R-electroless AISI 430 alloys at $800^{\circ} \mathrm{C}$ for $100 \mathrm{~h}$ dwell time. Microstructure and elemental compositional analysis, supported by literature reports, provides substantial information on the oxidation behavior. Further investigation is required at varying temperatures and isothermal dwell times for a comprehensive understanding of the oxidation kinetics of $\mathrm{Ni}-\mathrm{P}$ coated AISI 430 alloy.

\section{Conclusion}

The oxidation behavior of electroless $\mathrm{Ni}-\mathrm{P}$ coated AISI 430 and pre-reduced $\mathrm{Ni}-\mathrm{P}$ coated AISI 430 was investigated at $800{ }^{\circ} \mathrm{C}$ in moisture-saturated $\left(\sim 3 \% \mathrm{H}_{2} \mathrm{O}\right)$ air by microstructural and compositional analysis. The oxidation rate pre-reduced Ni-P coated AISI 430 is lower than electroless sample. $\mathrm{Ni}-\mathrm{P}$ coating crystallization and oxidation initiates the oxidation for the electroless sample while $\mathrm{Ni}_{3} \mathrm{P}$ and $\mathrm{FeNi}_{3}$ intermetallic compounds initiates the oxidation of the pre-reduced sample. Multilayered oxide scale with mixed oxide and spinel phases is formed by diffusion controlled oxidation mechanism in both the electroless and pre-reduced $\mathrm{Ni}-\mathrm{P}$ coated AISI 430.

Acknowledgements US Department of Energy funded the research under the Grant number: DE-FE 0023385. One author (MK) is grateful to NASA Alabama Space Grant Consortium (ASGC) Graduate Fellowship (Number: NNX15AJ18H) program. The authors thank Dr. Prabhakar Singh, University of Connecticut for helpful discussion.

\section{Compliance with ethical standards}

Conflicts of interest The authors declare, to the best of their knowledge, no conflict of interest in the manuscript.

\section{References}

1. Sudagar J, Lian J, Sha W (2013) Electroless nickel, alloy, composite and nano coatings - a critical review. J Alloys Compd 571:183-204

\section{SN Applied Sciences}


2. Kundu S, Das SK, Sahoo P (2014) Properties of electroless nickel at elevated temperature-a review. Proc Eng 97:1698-1706

3. Lee CK (2008) Corrosion and wear-corrosion resistance properties of electroless $\mathrm{Ni}-\mathrm{P}$ coatings on GFRP composite in wind turbine blades. Surf Coat Technol 202:4868-4874

4. Lee CK (2009) Structure, electrochemical and wear-corrosion properties of electroless nickel-phosphorus deposition on CFRP composites. Mater Chem Phys 114:125-133

5. Cheng YH, Zou Y, Cheng L, Liu W (2008) Effect of the microstructure on the anti-fouling property of the electroless $\mathrm{Ni}-\mathrm{P}$ coating. Mater Lett 62:4283-4285

6. Rani RU, Sharma AK, Minu C, Poornima G, Tejaswi S (2010) Studies on black electroless nickel coatings on titanium alloys for spacecraft thermal control applications. J Appl Electrochem 40:333-339

7. Mallory GO (1990) The fundamental aspects of electroless nickel plating. Electroless Plating: Fundamentals and Applications. Cambridge University Press, Cambridge, pp 1-57

8. Parkinson R (1997) Properties and applications of electroless nickel. Nickel Development Institute Publication, 33

9. Jordanov NB (2019) Electrodeposition of amorphous Ni-P layers, thermal treatment and corrosion behavior. Trans IMF 97:115-120

10. Yan M, Ying HG, Ma TY (2008) Improved microhardness and wear resistance of the as-deposited electroless $\mathrm{Ni}-\mathrm{P}$ coating. Surf Coat Technol 202:5909-5913

11. Sahoo P, Das SK (2011) Tribology of electroless nickel coatingsa review. Mater Design 32:1760-1775

12. Keong KG, Sha W (2002) Crystallisation and phase transformation behaviour of electroless nickel-phosphorus deposits and their engineering properties. Surf Eng 18:329-343

13. Schwartz M, Mallory GO (1976) Effect of heat-treatments on magnetic properties of electroless nickel alloys. J Electrochem Sci 123:606-614

14. Shong WJ, Liu CK, Yang P (2012) Effects of electroless nickel plating on 441 stainless steel as SOFC interconnect. Mater Chem Phys 134:670-676

15. Glazoff MV, Rashkeev SN, Herring JS (2014) Controlling chromium vaporization from interconnects with nickel coatings in solid oxide devices. Int J Hydrog Energy 39:15031-15038

16. Lin KL, Lai PJ (1990) Interdiffusion of the electroless Ni-P deposit with the steel Substrate. J Electrochem Soc 137:1509-1513

17. Weiss $Z$ (1992) High-temperature oxidation of iron covered by electroless Ni-P coating: a GDOS depth profiling study. Surf Inter Anal 8:691-694

18. Lo PH, Tsai WT, Lee J, Hung MP (1993) The study of interdiffusion phenomena of Ni-P/steel interface. Script Metal Mater 29:37-42

19. Eraslan S, Ürgen M (2015) Oxidation behavior of electroless Ni-P, $\mathrm{Ni}-\mathrm{B}$ and $\mathrm{Ni}-\mathrm{W}-\mathrm{B}$ coatings deposited on steel substrates. Surf Coat Technol 265:46-52

20. Mahapatra MK, Lu K (2011) Effect of atmosphere on interconnect-seal glass interaction for solid oxide fuel/electrolyzer cells. J Am Ceram Soc 94:875-885

21. Goldstein J, Newbury D, Joy D, Lyman C, Echlin P, Lifshin E, Sawyer L, Michael J (2007) Scanning electron microscopy and X-ray microanalysis, 3rd edn. Springer, New York

22. Pfeiffer H, Tancret F, Brousse T (2005) Synthesis, characterization and thermal stability of $\mathrm{Ni}_{3} \mathrm{P}$ coatings on nickel. Mater Chem Phys 92:534-539

23. Wojewoda-Budk J, Wierzbicka-Miernik A, Litynska-Dobrzynska L, Szczerba MJ, Mordarski G, Mosiałek M, Huber Z, Zieba P (2016) Microstructure characteristics and phase transformations of the $\mathrm{Ni}-\mathrm{P}$ and Ni-P-Re electroless deposited coatings after heat treatment. Electrochim Acta 209:183-191

24. Keong KG, Sha W, Malinov S (2002) Crystallization kinetics and phase transformation behaviour of electroless nickel-phosphorus deposits with high phosphorus content. J Alloys Compd 334:192-199

25. Connetable D, David M, Prillieux A, Young D, Monceau D (2017) Impact of the clusterization on the solubility of oxygen and vacancy concentration in nickel: a multi-scale approach. J Alloys Compd 708:1063-1072

26. Young J (2008) Enabling theory. In: Young DJ (ed) High temperature oxidation and corrosion of metals. Elsevier, Oxford, pp $31-84$

27. King MK, Mahapatra MK (unpublished work)

28. Hansson AN, Mogensen M, Linderoth S, Somers MAJ (2003) Inter-diffusion between $\mathrm{NiO}$ coating and the oxide scale on $\mathrm{Fe}$ 22Cr alloy. J Corr Sci Eng 6:H017

29. Taylor JR, Dinsdale AT (1983) A thermodynamic assessment of the Cr-Fe-O system. Z Metallkd 84:335-345

30. Pelton AD, Schmalzr H, Sticher J (1979) Computer-assisted analysis and calculation of phase diagrams of the $\mathrm{Fe}-\mathrm{Cr}-\mathrm{O}, \mathrm{Fe}-\mathrm{Ni}-\mathrm{O}$ and $\mathrm{Cr}-\mathrm{Ni}-\mathrm{O}$ systems. J Phys Chem Solids 40:1103-1122

31. Rhamdhani MA, Hayes PC, Jak E (2008) Subsolidus phase equilibria of the Fe-Ni-O System. Metal Mater Trans B 39B:690-701

32. Klug HP, Alexander LE (1974) X-ray diffraction procedures for polycrystalline and amorphous materials, 2nd edn. Wiley, New York

33. Tan YY, Sun DB, Yang B, Gong Y, Yan S, Du R, Guo HL, Chen W, Xing XQ, Mo G, Chen ZJ, Cai Q, Wu ZH, Yu HY (2013) In-situ crystallization study of amorphous Ni-P nanoparticles with high $\mathrm{P}$ content. In: Proc 13th IEEE Int Conf Nanotech, Beijing, China, August 5-8, 2013, pp 618-621

34. Atkinson A (1982) A quantitative demonstration of the grain boundary diffusion mechanism for the oxidation of metals. Philos Mag A 45A:823-833

35. Atkinson A, Taylor RI (1978) The self-diffusion of $\mathrm{Ni}$ in $\mathrm{NiO}$ and its relevance to the oxidation of Ni. J Mater Sci 3:427-432

36. Nakamura R, Lee JG, Mori H, Nakajima H (2008) Oxidation behaviour of $\mathrm{Ni}$ nanoparticles and formation process of hollow $\mathrm{NiO}$. Philos Mag 88:257-264

37. Lobnig RE (1992) Diffusion of cations in chromia layers grown on iron-base alloys. Oxid Metals 37:81-93

38. Okamoto H (2010) Ni-P (Nickel-phosphorus). JPEDAV 31:200-201

39. Pai ST, Marton JP (1973) The composition of oxides formed on electroless Ni-P deposits. J Electrochem Soc 120:1280-1281

40. Monty C (1983) Diffusion in stoichiometric and non-stoichiometric cubic oxides. Rad Eff 74:29-55

41. Brandes EA, Brook GB (1998) Smithells metals reference book, 7th edn. Butterworth Heinemann, Oxford

42. Birks N, Meier GM, Pettit FS (2006) Introduction to high temperature oxidation of metals, 2nd edn. Cambridge University Press, Cambridge

43. Shaigan $N$ (2010) A review of recent progress in coatings, surface modifications and alloy developments for solid oxide fuel cell ferritic stainless steel interconnects. J Power Sources 195:1529-1542

44. Takeda M, Onishi T, Nakakubo S, Fujimoto S (2009) Physical properties of iron-oxide scales on Si-containing steels at high temperature. Mater Trans 50:2242-2246

45. Ebbinghaus BB (1993) Thermodynamics of gas phase chromium species: the chromium oxides, the chromium oxyhydroxides, and volatility calculations in waste incineration processes. Comb Flame 93:119-137

46. Meier GH, Pettit ES (1992) The oxidation behavior of intermetallic compounds. Mater Sci Eng Al 53:548-560

Publisher's Note Springer Nature remains neutral with regard to jurisdictional claims in published maps and institutional affiliations. 